\title{
MONSTROUS HYBRIDS IN SHAKESPEARE'S KING LEAR
}

\author{
LOS HÍBRIDOS MONSTRUOSOS EN KING LEAR DE SHAKESPEARE
}

\author{
Agnès Lafont \\ Université Paul-Valéry Montpellier 3
}

\begin{abstract}
This article seeks to present the different languages (emblems, Renaissance translations of classical myths, biblical exegesis) that inform the images of monsters which, as hybrid creatures blending human and animal characteristics, serve a dramatic function in Shakespeare's King Lear. It means to question the ways in which the play links filial ingratitude with female monstrosity and Lear's madness. Tracing the classical and medieval lineage of the monstrous bestiary (serpent, tiger, vulture) in King Lear and connecting it to emblematic readings of Shakespeare's time, it explores how Shakespeare provides a dynamic characterisation of Goneril and Regan through their bestialisation. This study of teratogenesis then questions the notion of metamorphoses in the play.
\end{abstract}

KEYWORDS: Shakespeare; King Lear; emblem; mythology; ingratitude

RESUMEN: Este artículo intenta presentar los lenguajes diferentes (los emblemas, las traducciones renacentistas de los mitos clásicos, la exégesis bíblica) que informan las imágenes de los monstruos que, como criaturas híbridas que combinan características humanas y animales, sirven una función dramática en King Lear de Shakespeare. Procura interrogar las maneras en que el drama establece un vínculo entre la ingratitud filial, la monstruosidad femenina y la locura de Lear. Por trazar el linaje clásico y medieval del bestiario monstruoso (serpiente, tigre, buitre) en King Lear, y conectándolo con interpretaciones emblemáticas de la época de Shakespeare, explora cómo Shakespeare nos proporciona una caracterización dinámica de Goneril y Regan mediante su bestialización. Este estudio de la teratología procede a cuestionar el concepto de las metamorfosis en el drama.

PALABRAS CLAVES: Shakespeare; King Lear; emblema; mitología; ingratitud 
'Most monstrous' (5.3.157): Albany's exclamation hyperbolically underlines the horror and disgust he felt when confronted with Goneril and Regan's ungratefulness. ${ }^{1}$ The King of France was also surprised that Cordelia might have committed ' $[. .$.$] a thing so monstrous$ [...] Sure her offence / Must be of such unnatural degree / That monsters it [...]' (1.1.218221). A similar image is to be found in Lear's condemnation of his two other daughters: 'Down from the waist they are centaurs, though woman all above' (4.6.121-122). In English, 'monstrous' refers to monster, a hybrid, mythical creature that is 'part animal and part human, or combines elements of two or more animal forms, and is frequently of great size and ferocious appearance' $(O E D$ 1.), incorporating the most common Latin meaning to designate mythological beasts (Ruata, 2008: 113-34). The term monster, which is derived from the French monstre (OED, from Latin monstrare), is literally one that is 'monstered', or displayed, because of its deformities. A moral condemnation is thus intimately linked to the issue of representation in Shakespeare's play; indeed a monster could also be interpreted as a remonstrance or admonishment, that is to say a divine punishment sent after an offence. This specific etymology is attested in Tacitus's Annals (Tacitus, 1970: XII.43), in which monstrum is derived from monestrum (and therefore, from the Latin verb monere, meaning to warn). A monster then becomes a portent, an augury of divine admonition. The very existence of such a monstrous bestiary is tolerated by God's fair judgement precisely to admonish and punish since it is the outward manifestation of God's wrath.

In the early modern period, it is common to find mythological bestiaries, inherited from the preceding centuries, coexisting with scientific reasoning. During that time, the European cultural tradition favoured Pliny's Natural History (first-century AD) over Lucretius's De Natura Rerum (first-century BC) as a vector of scientific knowledge. Pliny, in his encyclopaedic compendium, presented a gallery of strange monsters, which were conversant with the patterns of the Renaissance imagination. This is perhaps why, even if Lucretius had already argued that monsters like centaurs never existed, most treatises in the Renaissance would have presented semi-human and semi-animal creatures as if their presence on earth had been attested. This conflicting and proto-scientific heritage is further taken up by other interpretive sources; thus emblem books also moralised the bestiaries inherited from the classical tradition and their more indirect medieval transmissions. Shakespeare's King Lear suggestively drew on all of these sources to inform the images of hybrid animals and their dramatic functions in the play-text: for instance mythology can be analysed as a pointer of perverted breeding (Peyré, 1996: 222-25) while Ovidian monsters can also be linked to the notion of metamorphosis in the play (Bate, 1993: 193-196). Shakespeare builds on the audience's prior knowledge and expectations of monsters to surprise them via emblematic vignettes, thereby revealing and mirroring the compound functioning of his drama.

A bestialisation process runs through the play-text using metamorphic images which are superimposed by Lear on two of his daughters. Goneril and Regan are intimately linked to

1. All references to the play are taken from Shakespeare, W. [1997]. King Lear, ed. R. A. Foakes, The Arden Shakespeare, $3^{\text {rd }}$ series London, Cengage Learning. This article expands work presented in seminars at Montpellier, part of which appeared in French as Lafont, A. [2008]. "'Most monstrous' (5.3.157): Métamorphoses et hybridations monstrueuses dans King Lear», in Lectures d'une œuvre, King Lear de William Shakespeare, S. Lemercier-Goddard (ed.), Temps, Rennes, 88-103. I wish to thank the anonymous reader for his comments as well as Daniel Yabut and Nicholas Myers for their helpful suggestions and friendship. 
three creatures, the serpent, the tiger, and the vulture, setting up a monstrous imaginary space which supplements the staged representation of their ingratitude. These filial figures in turn create a hybrid copia which disrupts Lear's world and contributes to his descent into tragic madness.

The notion of performative ingratitude underlies the organisation of the play: structurally, it can be analysed in the quarto and the folio versions of the text and, in addition on a metaphorical level, through a case study of the pelican image, which acts as a metatextual marker of converging traditions. Both of these types of analyses will show how discourses are taken apart and reassembled into a new hybrid figure.

In addition, an examination of two more syncretic images -that of the 'Centaur' (4.6.122) and of 'the sea-monster' (1.4.253) - will explore how Goneril and Regan's bodies serve as incarnations of these classical and biblical syntheses. The building of Lear's madness thus coincides with an intertextual process that leaves tensions unresolved in a monstrous and copious hybridity of discourses.

\section{CLASSICAL AND MEDIEVAL LINEAGE OF THE MONSTROUS BESTIARY IN KING LEAR}

\section{THE EMBLEMATIC THREAD}

Unpacking the classical and medieval lineage of the monstrous bestiary in King Lear may help contemporary audiences to grasp the play's imaginary backdrop. Thematically, monsters and ingratitude are linked in King Lear, as shown in several instances through the use of the snake emblem. 'Monster ingratitude!' (1.5.37) is born from the combination of a nightmarish bestiary and hellish fables. When Lear curses thus before imploring 'O let me not be mad!' (1.5.43), he clearly associates monsters with madness. It becomes apparent that the changes in the parent-children relationships are closely linked with the changes in Lear's mental health. Madness and monstrosity are the two sides, the former literal and the latter metaphorical, of metamorphosis in the tragedy.

\section{INGRATIS SERVIRE NEFAS: THE SNAKE IMAGERY}

This powerful thematic conflation illustrates the transgressive attitudes of Goneril and Regan towards their father after they rebelled against him, once empowered. Lear indicts Goneril's attitude with this simile:

She hath abated me of half my train,

Looked black upon me, struck me with her tongue

Most serpent-like, upon the very heart.

All the stored vengeances of heaven fall

On her ingrateful top! (2.2.348-52) 
This ironically echoes Lear's former misplaced condemnation of Cordelia: «How sharper than a serpent's tooth it is / To have a thankless child» (1.4.280-81). In the early modern period the snake, associated to the bestiary of the Bible, also recalls a well-known Aesopean fable (fabula 97). In England, Aesop's fables were available in Latin as early as 1530 and editions like AEsopi fabulae lectori non minorem fructum, quam florem ferentes...Index fabulas omnes inuenire docebit... (London: Guilielmus How., 1568) even provided an index. Aesop was translated into vernacular as well and The fables of Esope in Englishe with all his lyfe and fortune, ... vvhereunto is added the Fables of Auyan. And also the Fables of Poge the Florentyne very pleasaunt to reade (London, John Waley, 1570) was several times reprinted. But this story is popularised by emblem books and their powerful imagery. Nicolas Reusner, in Emblemata, uses this story to blame ungratefulness in an emblem entitled: 'Merces anguinas' (1581: II.22). In addition, 'to warm a viper in one's bosom' was a known phrase:

Ingratis seruire nefas, gratisque nocere:

Quod bene fit gratis, hoc solet esse lucro.

Ingratis servire nefas ('to serve the ungrateful is an offense to the gods') is also the motto of a later Spanish emblem by Juan de Horozco y Covarrubias, in Emblemas Morales (Segovia, Juan de la Cuesta, 1589), which recalls the story of a snake, which bit the hand of his benefactor (II.14). Sebastián de Covarrubias Orozco in his Emblemas Morales (Madrid: Luis Sánchez, 1610) echoes this. This reading of the serpent's treacherous behaviour is widespread in European emblematics, as is shown by Henry Peacham's contemporary emblem book entitled Minerva Britanna, which includes an indictment of libidinis effecta, or lust's effects (Peacham, 1612: 152):

\footnotetext{
The viper when he doth engender, loe,

Thus downe the females throate, doth put his head,

Which of the bites, as learned Authours show,

And ne're conceives, before the male be dead:

Eke when she forth, her poisonous broode doth send,

Her young ones likewise, bring her to her end. [...]

Daughter of Sloth, vile cancker of the mind,

Leaving repentance, and soule shame behind.
}

This emblem shows how ingratitude and snakes are physically and morally associated within the family. Referring indirectly to another story, this time reported by Pliny, the emblem recalls that the she-serpent may get her womb ripped by her younglings when she gives birth; in essence they kill their mothers by their very birth (Peyré, 1996: 225). As can be seen, emblematic imagery combines several classical influences, «learned authors», to insist on female cruelty -and to the fact that this cruelty shall be paid for. Hybridity thus operates on two levels: in the circulation of the image as well as in the image itself.

\section{IMPOTENTIS VINDICTAE FOEMINA: THE WOMAN-TIGER}

While offering a syncretic transmission of classical influences, this process also creates powerful hybrid textual images by bringing together references to several beasts. The woman-serpent is for instance combined with the woman-tiger. In the quarto edition, Albany 
exclaims, 'Tigers, not daughters, what have you performed?' (4.2.41). Once again, as with the viper motif, masculine and feminine characteristics are conflated: in this case, through the use of leonine rhyme, marked by the caesura.

Yet, this is a common feature in emblematic language as well. Women have often been compared to tigers due to their uncontrollable cruelty towards their children. For example, Barthélemy Aneau in Picta poesis (Lyons, 1552) wrote that women are unable to control their desire for revenge ('impotentis vindictae foemina'):

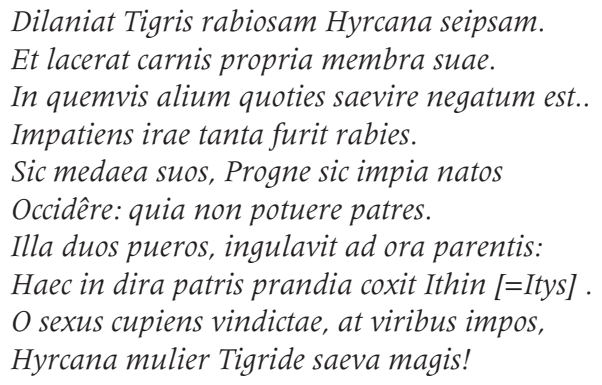

[The rabid Hyrcanian tigress tears herself to pieces, and rends the members of her own flesh. No other target presents itself, and her rage, unable to control its anger, is so powerful in its madness. So Medea, so evil Procne killed their children because they could not kill their fathers. The one slit her two sons' throats in their father's face; the other cooked Itys into a monstrous lunch for his father. O female sex, desiring revenge on your husbands but unable to carry it off; O woman, more fearful than a tigress of Hyrcania!]

Infamous Ovidian stories of Medea and Procne, who killed their offsprings, reverberate in the cruelty of the natural beast, which may kill its family when taken by rage. Moreover, classical authors like Virgil (1999: 447) also mention this type of cruelty by female tigers. Here Dido reproaches Aeneas with leaving her and insists on his lack of love:

\section{Talia dicentem iamdudum auersa tuetur \\ huc illuc uoluens oculos totumque pererrat \\ luminibus tacitis et sic accens aprofatur: \\ 'nec tibi diua parens generis nec Dardanus auctor, \\ perfide, sed duris genuit te cautibus horrens \\ Caucasus Hyrcanaeque admorunt ubera tigres}

[As thus he spoke, all the while she gazes on him askance, turning her eyes to and fro, and with silent glances scans the whole man; then thus, inflamed, cries out: 'False one, no goddess was your mother, nor was Dardanus founder of your line, bur rugged Caucasus on his flinty rocks begot you, and Hyrcanian tigresses suckled you']

Seneca, another classical locus for maternal cruelty, quoted here in Studley's English translation of Medea also refers to the tiger's «savage brutysh tyranny» (Studley, 1566: n.p.).

'Exyle all folysh female fear / And pytye from the mind / And as th'untamed Tygers use / to rage and rave unkynde, / that haunt the crokyng combrus caves /and clumpred frozen clives, /And craggy rockes of Caucasus, / Whose bytter colde depryves / The soyle of all inhabytours, /permyt to lodge and rest, / Such savage brutysh tyranny within thy brazen breste'. 
This becomes something of a commonplace in the period, repeated in various contexts (Tassi, 2011: 199; Herrick, 1966: 559-571). ${ }^{2}$ What Shakespeare does in King Lear is a hybrid out of the emblematic code: the tiger's cruelty is combined with the serpent's ingratitude, using the linking element of female monstrosity. The emblem then provides another layer of intertextuality by adding Ovidian mythological tales about mothers killing their offspring to take revenge against their husbands. The subtext of Aneau's well-known emblem that Shakespeare may be employing is that Regan and Goneril are worse than animals, and worse than their mythological female precedents: not as women who kill their children because their husbands are out of reach, but as daughters who rebel against their fathers. Mythology is here on the competitive mode.

In another emblem from Minerva Britanna that associates female excess with uncontrolled ingratitude, Henry Peacham condemns political rebellion against one's monarch in 'Regum Maiestatem non imminuendam'. He precisely associates these two animals: 'Vile traytor, of some Hyrcane Tiger bred, / Such serpents still, thy soveraignes crowne do guard' (Peacham, 1612: 137). This political reading appears to duplicate Albany's condemnation of Goneril and Regan in the quarto edition quoted above, and recalls the portrait of Goneril, with her "Wolvish visage» (1.4.300), as sketched by her father's indignant rhetoric. These fiendish animals thus become ciphers of Lear's daughters' unnatural behaviour. The process of copia at stake functions in a cumulative manner and enhances subterraneous male fears in the play: consumption and cannibalism.

\section{PETRARCHIST TRADITION AND MYTHOLOGICAL READINGS: THE VULTURE-WOMAN}

Another argument points to the copious emblematic hybridity inherent to the play-text. The vulture image, borrowed from the natural world, echoes a well-known Petrarchist tradition exemplified by sonneteers in the 1590s as well as in a reading of Titius's plight in the classical fabula. Commenting on Goneril's attitude to Regan, Lear borrows what is ironically a stock image in love sonnet sequences:

O, Regan, she hath tied

Sharp-toothed unkindness, like a vulture, here. (2.2.323-24)

Betrayal and punishment are once more associated through the hybrid combination of traditions. This simile has several layers: if the woman-vulture refers to the traditional bestiary of 'natural' cruelty because it evokes the image of a bird preying upon decaying flesh, then the allusion to this animal also taps mythological fables. The vulture belongs to the classical fabula of Titius, and, in the Renaissance, this myth is read as a divine punishment, which may be caused here by the division of Lear's state to his daughters.

A recurring mythological cluster of the Renaissance imagination associates four damned figures who have been condemned to eternal suffering in the underworld (Ovid, Metamorphoses, 4.456-463): Ixion (father to the Centaurs), Sisyphus, Tantalus and Titius. Their proximity (due to their hubris), their transgressive nature, and the exemplarity of their

2. I'd like to thank F. Delord for the reference to Studley's Medea in 'O tiger's heart wrapped in a woman's hide! - Hyrcanian Tigresses in Shakespeare', Shakespeare and Myth (ESRA Conference, Montpellier, 26-29 June 2013), unpublished article. 
punishments, often results in a reference to one of them calling for an allusion to another one. Thus, the allusion to Ixion's wheel (4.7.46-48) would call for Titius's liver being torn out by a vulture. The latter's predicament was read in the Renaissance as the pain that is brought on by everlasting penance; Guillaume de la Perrière explains in Morosophie (La Perrière, 1553: 1658):

Jamais meschant ne veit sa peur extainte:

Quand l'une fuyt, l'autre vient de retour:

Comme l'on void, qu'en la figure peinte,

Titius est rongé par le Vautour

['A villain always suffers from fears / when one ends another comes / as we can see in the picture / where Titius is gnawed by a vulture' (my translation)].

Titius is associated with lechery because he tried to rape Latona, the mother of Diana and Apollo, which marks him as an exemplum of lust. When applied to Lear, however, these lines may also turn him into a Promethean figure, ${ }^{3}$ whose torture was seen as a symbol of the gnawing pains occasioned by passions. This is especially evident in the love sonnets of the period, as seen for example in Barnabe Barnes's Sonnet 61, in Parthenophil and Parthenope (1593):

To none but to Prometheus me compayer,

From sacred heauen he stoule that holy fier:

I from thine eyes stoule fier, my iudgements are

For to be bound with cheanes of strong desier

To that hard rocke of thy thrise cruell hart:

The ceaselesse waues, which on the rockes do dash

Yet neuer pearce, but forced backward start

Those be these endlesse teares, my cheekes which wash:

The vulture which is by my goddesse doome

Assign'd to feede upon mine endlesse lyuer,

Dispaire by the procur'd, which leaues no roome

For Ioculus to iest with Cupides quyuer:

This swallowes worldes of liuers, spending few,

But not content: O god shall this be true?

Barnes's sonnet is typical of the English reception of the continental production of the period (Barnes, 1593: 41 and sonnet 30, 19). In the French Pléiade, poets also used the motif of the vulture as a figure of the love tormentor. Gisèle Mathieu-Castellani has interpreted the reference to Prometheus in love sonnets as an indirect characterisation of the destructive and perverse Mannerist Eros; the image of the woman thus created is that of an insatiable creature who finds pleasure in the destruction of male virility (Mathieu-Castellani, 1981: 149-50). ${ }^{4}$ Goneril, the fiercer daughter who will poison her sister to attain

3. On other aspects of this myth, see Gaëlle Ginestet, «Ixion», in A Dictionary of Shakespeare's Classical Allusions, ed. Yves Peyré (UMR 5186, CNRS - Université Paul Valéry - Montpellier III, 2009).

4. The quote reads «[...] l'identification de l'amour au vautour permet de designer le caractère fondamentalement destructeur d'Eros, et de lire en filigrane sous cette mise en accusation une image mauvaise de la femme [...] Ici le mythe prométhéen ne dit pas la grandeur de l'homme, ni l'audace d'un projet qui vise à détrôner les dieux, mais, dévitalisé et amoindri, la terreur que suscite la femme-Vautour, difficile à satisfaire, ne trouvant sa volupté que dans la destruction de la force virile» (Mathieu-Castellani, 1981: 149-50). ['To identify love with the vulture is to point out the fundamentally destructive function of Eros and also to surreptitiously assign a negative image to women [...] Here the Promethean myth does not glorify men, nor the boldness of a design meant to 
her aims, is also the more lecherous one. Yet what is addressed in this motif is unkindness. From sonnet to tragedy, the reference to the Promethean punishment becomes less specific but still expresses an acute suffering. The fact that the myth is not mentioned but only referred to indirectly, by means of the vulture, contributes to erase the amatory subtext of this mythological allusion. What matters here is the intertwining of discourses, its effects being heightened when its components are made less apparent.

This punishment is indirectly taken up by the Fool when he addresses Kent with what is a likely allusion to Sisyphus's rock (Soellner, 1984: 280-81). The ever-falling rock superimposes its fall on the turn of the wheel of Fortune to recall everlasting torments: 'Let go thy hold when a great wheel runs down a hill lest it break thy neck with following it; but the great one that goes upward, let him draw thee after' (2.2.261-63). Hellish and fiendish creatures, issued from the animal world, intersect with the sorry gallery of the damned of the underworld to set up Lear's tormented and suffering kingdom before the audience. The monstrous bestiary thus becomes a place of remonstrance, or of punishment. In Lear's own words, animal similes refer to bestiality, thereby revealing the devilish nature of his monstrous daughters; their exemplary transgressing attitude is underscored by the blending of this hellish bestiary with the classical figures of the accursed in the underworld, condemned by the Gods for their hubris.

Furthermore, George Sandys, one of Ovid's later English translators in the Renaissance, provides a psychological reading of these divine punishments in Ovid's Metamorphosis Englished (1632):

All these aforementioned punishments allegorically referred to the perturbations of the mind [...] Ixion's wheele [sic], to the desperate remembrance of perpetual crimes, which circularly pursue, and afflict the guilty. (Sandys, 1970: 163)

Once again, madness and punishment are associated. In King Lear, the bestiary reveals the aesthetics of a multi-layered composition: paradoxically the emblematic reading of mythological fables is given full symbolic significance at the very moment when a new philosophical discourse on animals is brought to the fore (Fudge, 2002: 28). This bestiary, taken from several mythological fables as well as from various classical sources, via emblems, poetry and engravings, underlies a hybrid composition which in turn reflects the monstrous metamorphoses at stake in the play.

\section{PERFORMATIVE INGRATITUDE AND THE 'PELICAN DAUGHTERS'}

Metamorphosis lies at the heart of the perturbations in the play: the changeable and complementary interpretations imported from emblem books and other literary discourses that help characterise the daughter/father relationships correspond to textual metamorphoses of the play-script itself as well as metamorphoses of the shifting images thus provided.

supersede the gods, but, enfeebled and de-vitalised, the mythological allusion deals with the fear of a VultureWoman, difficult to satisfy, and finding her pleasure only in destroying masculine power' [my translation]. 


\section{STAGED METAMORPHOSIS?}

First, depending on which edition of the play-text we analyse, this monstrous metamorphosis may be read either as a process or as a result. So, two different strategies are at work in the quarto and in the folio. Whereas metamorphosis is explicitly mentioned in the 1608 quarto at 1.32-51, this condemnation of Goneril's inhumanity remains unsaid in the 1623 folio, which omits 1.32-51 and transforms the reference to monstrosity into a biblical condemnation:

Albany. See thyself devil:

Proper deformity shows not in the fiend

So horrid as in a woman (First Folio, 1623: 4.2.60-62)

In the quarto version, however, this passage was longer:

Albany. Thou changed and self-covered thing, for shame

Bemonster not thy features. [...]

Howe'er thou art a fiend,

A woman's shape doth shield thee. (Quarto, 1608: 4.2.63-68)

How can we account for this difference? John Jowett, in Shakespeare and Text, holds that the rewriting of Folio King Lear is authorial:

The alterations manifested in Folio King Lear were not primarily structural and go beyond the theatrical need to adjust the text for a revival in a different theatre [...] [T] he revision has an authorial rather than a theatrical complexion. (Jowett, 2007: 42)

Jowett reminds us that the Folio was not available to readers in Shakespeare's time. He adds that the alterations in the text's two versions are from Shakespeare's hand, and therefore, both texts are valid readings (Jowett, 2007: 1-2; see also Foakes, 1997: 142-44). Consequently, while metamorphosis is ongoing in Albany's tirade in the 1608 quarto, it is considered as fully achieved in the later folio in Albany's simple line, 'See thyself, devil'. Whereas one presents an identity crisis (the moment when the metamorphosis is staged), the other clearly shows a de-humanised being, as the neologism 'be-monster' strongly emphasises. ${ }^{5}$ The quarto also presents more occurrences of metamorphic elements, and monstrous preying is seen as a divine punishment. Terrifying jaws eat up their own kind, their own children, and family cannibalism surfaces once more in Albany's words in the quarto: 'Humanity must perforce prey on itself, / Like monsters of the deep' (4.2.50-51). This passage is one of three in this scene that are to be found only in the quarto.

\section{'[T]HE PELICAN IN HER PIETY': FATHER AND DAUGHTERS}

A metamorphic functioning is also at stake on an emblematic level. In the Renaissance, the Christian image of the pelican was routinely understood as an allegory of the ideal parent who tears his or her own flesh to nourish his or her children. At the end of the period,

5. In the Oxford English Dictionary, the first occurrence of the term 'be-monster' in English is attributed to Shakespeare's King Lear.

IMAGO, NÚM. 8, 2016, 107-123 
the commonplace reading of the pelican may be found, for example, in George Wither's $A$ Collection of Emblems, Ancient and Modern (1635): 'Our Pelican, by bleeding, thus, / Fulfilled the law, and cured us' (III.20). It was famously represented in connection with Elizabeth I's portraiture in the so-called 'pelican' portrait (c. 1575, attributed to Nicholas Hilliard, National Portrait Gallery, London), and the Queen is described by John Lyly as 'the good pelican that to feed her people spareth not to rend her own person' (Euphues, 2.215, STC (2nd ed.) / 17051).

Yet we have to go back to the medieval period to find the full story of the pelican. Guillaume Le Clerc's Bestiaire, or Bestiaire divin (c. 1210-1211) drew from Isidore of Seville's Etymologiae and provided us with the complete fable:

There is a wonderful thing about the pelican, for never did mother-sheep love her lamb as the pelican loves its young. When the young are born, the parent bird devotes all his care and thought to nourishing them. But the young birds are ungrateful, and when they have grown strong and selfreliant they peck at their fathers face, and he, enraged at their wickedness, kills them all. On the third day the father comes to them, deeply moved with pity and sorrow. With his beak he pierces his own side, until the blood flows forth. With the blood he brings back life into the body of his young. ${ }^{6}$

In the Renaissance, this image has been only partially transmitted and can be found in a variety of forms (like church's misericords) illustrating 'the pelican in her piety'. In some illustrations, the mother feeds her blood to her chicks or the chicks reach up for the drops of blood.

When Lear describes his children as 'pelican daughters' ('[...] 'twas this flesh that begot / Those Pelican daughters' (3.4.73-74)), he is not referring to the standard Renaissance reading of the image, but rather echoing the first part of the medieval story. This traditional image of tamed cannibalism used by Lear to describe his daughters to Poor Tom is inverted: he does not refer to the episode when he gives his own flesh to provide sustenance to his kind, but instead to the episode when the chicks attack their nourishing parent; Lear's own daughters feed on him, vampire-like. The image of the division of the kingdom, symbolised by the division of the King's fantasised body, is monstrously bred by the King's own actions and words; this conventional Christian -and political- emblem, which may seem univocal, is thus re-fashioned to become a teratomorphic emblem of the cannibal and unnatural child, harkening back to medieval readings of the figure. ${ }^{7}$ It ironically echoes Lear's initial violent condemnation of Cordelia:

The barbarous Scythian,

Or he that makes his generation messes

To gorge his appetite, shall to my bosom

Be as well neighboured, pitied and relieved

As thou my sometime daughter (1.1.117-21)

6. L. O. Kuhns. [1896]. Bestiaries and Lapidaries, in Library of the World's Best Literature, ancient and modern, vol. 4, London, Connoisseur Edition, offers a loose translation of Guillaume Le Clerc's Bestiaire, or Bestiaire divin (drawing from Isidore of Seville's Etymologiae (composed 1210-1211). See also Bartholomaeus Anglicus (13 ${ }^{\text {th }}$ century), De Proprietatibus Rerum, XII.

7. The same distorted use of the emblem can be noted in Gaunt's cue to Richard in Shakespeare's Richard II: 'O, spare me not, my brother's Edward's son, / For that I was his father Edward's son. / That blood already, like the pelican, / Hast thou tapped out and drunkenly caroused' (2.1.124-27). Once again, the image of the pelican connotes ingratitude, whereas Laertes in Hamlet offers a more Christian use of the figure: '[...] like the kind liferend'ring pelican, / Repast them with my blood [...]' (4.5.147-48). All references to Shakespeare's plays taken from Shakespeare, W. [2007]. Complete Works, J. Bate and E. Rasmussen (ed.), London, Macmillan. 
From the start, the problematic child-parent relationship is established (Quilligan, 2005: 213-35). The allusion to barbarous rites becomes a means of dehumanisation, and it condemns ingratitude as a non-civilised, non-human feeling. Monsters are thus implicitly associated with lasciviousness, which is redefined as monstrous proliferation in a form of disorganised breeding:

Let copulation thrive

For Gloucester's bastard son was kinder to his father

Than were my daughters got 'tween the lawful sheets. (4.6.112-14)

Dramatic irony blinds Lear when he thus addresses Gloucester, who, as the audience already knows, has been betrayed by Edmund. Betrayal is not confined to children begot out of wedlock; rather, it spreads in all homes. The fruit of this debauch is a semi-human and semi-animal creature: the centaur, as mentioned by Lear in 4.6.121-22. Ironically, once more, even if Edmund refused the influence of bestial zodiacal signs on his unnatural behaviour, their evocation provides a useful gloss of his character for the audience:

An admirable evasion of whoremaster man, to lay his goatish disposition on the charge of a star. My father compounded with my mother under the dragon's tail and my nativity was under Ursa Major, so that it follows I am rough and lecherous. Fut! I should have been made that I am had the maidenliest star in the firmament twinkled on my bastardizing. (1.2.126-33)

What is monstrous is also what inverts natural order: children become their parents' parents. The Fool mocks Lear: 'Thou mad'st thy daughters thy mothers; [...] I marvel what kin thou and thy daughters are' (1.4.164-73), Cordelia laments because she sees 'a childchanged father' (4.7.17) and she refuses that he should kneel before her. She thus restores the accepted order of the child-parent relationship. This is contrary to her sister, who had accepted her father's humiliation in Act 2, where Lear kneeled before Regan in a visually staged emblem of the inversion of the child-parent relationship (2.2.343-47). Edgar, using a simile in which the vehicles are inverted in a chiasmic pattern, compares his destiny of banished son to that of Lear as a banished father: 'He childed as I fathered' (3.6.107). Sons breed like their fathers while these fathers become children again. Stylistic innovation here gives full force to the monstrous reversibility of the child-parent relationship.

\section{CLASSICAL AND BIBLICAL SYNTHESES}

The figure of the monster, as used by Lear to qualify his daughters, thus makes it possible to distinguish between reproduction and repetition: the father denies that his daughters may have been conceived by him because they do not bear any likeness to him; that is what illustrates the perverted image of the pelican. At the same time, however, he keeps repeating that they are his children, which raises questions about the tragic deadlock leading to his madness. Lear then implicitly becomes one of these criminal breeders, another Ixion (Hardison, 1975, 227-42; Bate, 1993: 196), the father of the Centaurs, as he confesses to Goneril:

But yet thou art my flesh, my blood, my daughter,

Or rather a disease that's in my flesh,

Which I needs call mine (2.2.410-12)

IMAGO, NÚM. 8, 2016, 107-I23 
Centaurs were the children that Ixion begot of a cloud-woman, Juno's imaginary double. The centaur is a complex figure: read in bono, it may refer to virtuous Chiron, in charge of Achilles or Aesculapius's as well as other heroes' education. Alciato's emblem 145, entitled Consiliarii Principium or 'The Prince's advisors', illustrates this emblematic reading of the figure and shows a centaur in the engraving. However, combining human and equine characteristics, they also appear as wild and violent, and showing a degraded humanity. Even a Chiron retains a potential for violence (Alciato, 1584: emblem 145). Moreover the zodiacal centaur, often represented with hypertrophied male genitalia (Rowland, 1974: 534), symbolises lust, darting his arrow. ${ }^{8}$

\section{'DOWN FROM THE WAIST THEY ARE CENTAURS THOUGH WOMAN ALL ABOVE' (4.6.121-22): THE WOMAN CENTAUR}

Teratogenesis also functions through the blending of scientific and symbolic discourses. Hybridisation, interpenetrations, and cross-encounters appear to result from feminine monstrosity, when medical, symbolical, and mythological languages are reorganised around the pivotal figure of the female centaur. In the early seventeenth century, at a moment when a new medical discourse was emerging, ${ }^{9}$ the meaning of the term monster underwent several shifts in literary and artistic works due to the influence of the numerous monsters to be found in the canons of classical authors. Though no centaur is to be found in Conrad Lycosthenes's famous Prodigiorum ac ostentorum chronicon (Basel, H. Petrus, 1557), the story does feature a semi-female and semi-quadruped creature, which bears testimony to the importance of the precision of classification and medieval-type compilation over verisimilitude in Renaissance culture (Lycosthenes, 1557: 666). The centaur does however figure into King Lear: 'Down from the waist they are centaurs though woman all above' (4.6.121-22). The figure of the monster is thus associated with the dehumanisation of Lear's daughters, which is primarily due to the breaking of the natural bond of child-parent relationships.

Furthermore, after Gloucester's blinding, a servant fears that Regan's cruelty may contaminate the whole female sex:

If she [Regan] live long

And in the end meet the old course of death,

Women will all turn monsters (3.7.99-101)

While the daughters are turned to monsters, the father is feminized, infected by hysteria, another name for madness, which is also referred to in English as "mother».

O, how this mother swells up toward my heart!

Hysterica passio, down you climbing sorrow,

Thy element's below. Where is this daughter? (2.2.246-48)

8. This is played upon in Shakespeare's Othello when Iago tells Roderigo '[...] That you shall surely find him, I Lead to the Sagittary the raisèd search, / And there will I be with him' (1.2.166-168). Shakespeare, W. [2007].

The Tragedy of Othello, The Moor of Venice in Complete Works, J. Bate and E. Rasmussen (ed.), London, Macmillan.

9. See, for example, Ambroise Paré's Les Monstres et les prodiges (1573, reprinted in 1585), as well as the informative book exhibition: http://www.bium.unaiv-paris5.fr/monstres/debut.htm [accessed 4 November 2016]. 
This is Shakespeare playing with scientific knowledge: dissection had already enabled Galen in second century AD to show the impossibility of a migration of the female matrix, which was formerly believed to be a cause of female madness. Jean Fernel (1497-1558), in Pathologie, defended the idea of a vapour that could reach the brain and cause female madness and hysteria. In King Lear, by translating the vocabulary of female madness in Lear's sorrowful words, Shakespeare combined symbolic terms with scientific notions of his time: the term Mother also embodied the concept of Nature; and it is a revolution in the order of Nature that is shown in the play. The world's symbolical order is disrupted, which results in madness: a mental manifestation of the chaos that reigns over Lear's divided kingdom. Symbolical discourse superimposes itself onto medical and mythological discourses, thus conveying the idea of a divine punishment that turns Lear into another helpless Ixion, Titius, or Prometheus, as Lear becomes the accursed man bound to his wheel, with his entrails gnawed by his daughters.

Gradually, a poetics of madness that monsters itself, or even de-monstrates itself, emerges. The mythological monster, created by the interaction of classical and biblical sources, is typical of the Renaissance culture of borrowings. In Lear, it is through the ways in which madness is conceived and ingratitude is depicted, that a monstrous tapestry is weaved, a sick setting for a troubled, fantasised world. These different subtexts unveil a cultural background which 'informs' the audience's reception at the time.

The assembling of history and myth suggests many monstrous combinations which emphasise Lear's defective judgement and his children's ingratitude. In his article, «Myth and History in King Lear», O. B. Hardison successively traced the textual elements of the Ixion fable, thus showing the reverberation of the myth throughout the play:

[...] The Ixion myth had a general influence on the play, extending from the first scene to the last; unlike Sackville and Norton, Shakespeare did not use myth for organisation. His major source was already in dramatic form, and he should readily have any dramatic deficiencies without recourse to mythology. The most striking fact about the parallels noted is that they are ideological. The myth of Ixion supplied Shakespeare with the philosophical issues in terms of which the action of the play is developed. (Hardison, 1975: 228)

History, when read in light of myth, is enriched with new figures inherited from a classical background. In quoting Pindar in his second Pithian Ode, Hardison reminds us that the figure of Ixion has represented ingratitude since Antiquity.

Hardison suggests that the myth functions in retrospect and that it makes the whole question of ingratitude reverberate in the general structure of the play:

Ixion, as he whirleth round and round on his winged wheel, by the behest of the Gods, teacheth his lesson: men should requite the benefactor with fresh token of gratitude. (Hardison, 1975: 231)

Lear's exclamation to Cordelia, which echoes other allusions to the wheel of fortune in the play (as fitting in a de casibus tragedy), offers a nodal point that simultaneously refers to the imagery of monstrous ingratitude and to perverted procreation, since Ixion is the father of Centaurs:

Thou art a soul in bliss, but I am bound

Upon a wheel of fire, that mine own tears

Do scald like molten lead (4.7.46-48)

IMAGO, NÚM. 8, 2016, 107-123 
Another line of analysis, as suggested by Jonathan Bate, recalls another key function of mythological allusions:

[...] An allusion may signal a far more reaching correspondence, but it may be incidental or ornamental; an affinity may be made apparent on the surface of the text, but it may operate at the level of the imagination. Paradoxically, the most profound affinities may be the least demonstrable precisely because they go deeper than the explicit local parallel. (Bate, 1989: 135)

Bate's 'method of affinities' is used to demonstrate Ovid's Metamorphoses influence over King Lear. This metamorphic principle underlies the entire play, whether it be the metamorphoses undergone by Lear's two unnatural daughters, or metamorphoses of Lear himself, who gradually becomes mad while at the same time believing he may become king again:

thou shalt find

That I'll resume the shape which thou dost think

I have cast off for ever. (1.4.300-302)

Lear's mental metamorphosis is reflected by Edgar's disguise into poor Tom:

I will preserve myself, and I am bethought

To take the basest and most poorest shape

That ever penury in contempt of man

Brought near to beast $(2.2 .177-80)$

Once more, the image of the wheel as an emblem of mutability accounts for a metaphoric reading of metamorphosis (Bate, 1989: 144). These two critical approaches are not contradictory; rather, they supplement each other since the compiling activity of the mythographers is one of the privileged vectors of the cultural spreading of the classical heritage in the medieval and Renaissance periods. Even if the humanists read texts in their original languages, Shakespeare and his contemporaries were also dependent on dictionaries, emblem books, and engravings, which offered varying glosses and versions of the same fabula. Thus, in order to explore notions of ingratitude, founded on monstrous figures, Shakespeare borrowed not only from classical sources but also from contemporary -and specifically, emblematic- readings of these sources.

\section{DAUGHTERS 'MORE HIDEOUS [...] THAN THE SEA MONSTER' (3.2.57)}

Classical and biblical intertexts engender a hybridisation of influences that begets hybrid daughters 'more hideous [...] than the sea monster' (3.2.57). Monsters 'from the deep' is an image which partakes of multiple, simultaneous origins. To interpret myths and to analyse the structure of the workings of Renaissance imagination is also to trace a number of commonplace notions that can be found in the metaphorical writing of a play. Physical and psychological metamorphoses of the characters onstage are linked to question the uncertainty of the human condition and the instability of human relationships. This 'seamonster' can also be viewed as an allusion to the Leviathan (Psalm 74.14-15). The devilish 
bestiary of the Middle Ages is fuelled by illuminated manuscripts and eastern culture: in its illustration of the Last Judgment, Roman sculpture shows the damned being thrown into the gaping jaws of this biblical monster (Book of Job). In the Renaissance, the whale is seen as another symbol of the Leviathan. It is represented in Sebastian Münster's (1489-1552) Cosmographia Universalis (Basel, 1544, followed by twenty-four reprints), which is shown eating up human figures.

The compounding of several of these influences in King Lear is typical of the way creation springs from hybridisation in the Renaissance. Bate believes that sea monsters in Shakespeare's works are directly inspired by Ovid's Metamorphoses:

I would say that the image conflates two of the monsters slain by Perseus: «marble-hearted" and "hideous" come from the grotesque Gorgon's head which turns to stone and the sea monster itself is that from which Perseus saves Andromeda. (Bate, 1989: 143)

Like other critics (Peyré, 1996: 224n.103), I am not totally convinced by this reading. However, Bate also briefly suggests an idea espoused by Reginald Foakes in the Arden Shakespeare edition of King Lear: this could also be an allusion to the fabula of Hercules rescuing Hesione, daughter to the Trojan Laomedon, when she was attacked by a sea monster sent by Neptune (Bate, 1989: 194 n.33). The context in which this mythological image was inserted into The Merchant of Venice (3.2.54) is vastly different than the context in King Lear, because of the amatory thematic and generic choices. Thus, the sea-monster image serves different purposes in the two plays. In The Merchant of Venice, Portia makes the allusion in her heroic characterisation of the young lover Bassanio:

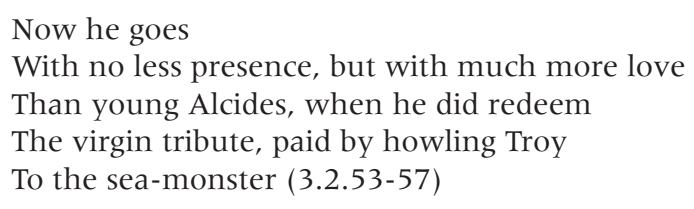

According to the Ovidian tale, inherited from Homeric sources, Laomedon's punishment is due to his numerous perjuries. First, he refused to pay Apollo and Neptune for their building of the Trojan surrounding wall. Then, when Hercules killed the sea monster that was sent to punish the King for his ingratitude, Laomedon refused to gratify him. Hercules, infuriated, came back with an army, took Troy, and killed Laomedon and all of his sons except Priam. In The Merchant of Venice, the allusion clearly leaves out the theme of punished ingratitude, whereas in King Lear, this reading appears to fit perfectly with the imagery. Thus, Foakes's suggestion is efficient in terms of the illustration of the theme of ingratitude and of punished monstrosity.

The analysis of monstrous figures in King Lear through emblematic lenses, building on O. B. Hardison's analyses bearing on the structure of the play, on Peyré's structural and symbolical perspectives, and on Bate's tracing of Ovidian sources within the tragedy, serves to combine these different approaches with the study of the emblematic bestiary and medical discourses of the medieval and early modern period. When humanity is construed through the emblems of beasts and monsters, the cross-hybridisation of the various discourses raises questions concerning the primary themes of the play as well as the early modern psyche about family relationships. The monsters in Lear serve not only as divine punishments; they also offer characterisation. Goneril and Regan are described in terms of monstrosity com- 
bined with lasciviousness. From their lack of measure, 'indistinguished space of woman's will' (4.6.265), they are associated with the damned figures of the underworld and serve as foils to Cordelia's purity. In addition, the monstrous imagery sets a transgressive tonality while also conveying a hellish portrait of the divided country. The monster is therefore etymologically the sign of a malfunction, as suggested by Robert Ellrodt: 'the real subject of King Lear [...] is not the destruction of an ancient order -the feudal order- by a new order, but the collapse of an ancient order which dies because of its own contradictions' (Ellrodt, 2002: 1357, my translation). This was masterfully rendered by Trevor Nunn in the Royal Shakespeare Company production of King Lear in 2007 in which the setting gradually fell apart and literally collapsed as the play progressed (Wells, 2007: 87-92). The very principle of metamorphosis, intimately linked to the question of monstrosity in Lear, commands the composition of the plot and the psychological evolution of the characters at the very heart of the tragedy, which is achieved differently in the two versions of the text. At the same time, the seeds of destruction are contained within these discourses that blend and intersect, echoing medieval and contemporary continental readings and conveying tragic violence and symbolic meanings, while the very workings of King Lear's composition by hybridisation meta-poetically reflects how monstrous ingratitude indeed operates.

\section{BIBLIOGRAPHY}

Alciato. [1584]. Emblemata, Paris: Jean Richer.

Anonymous. [1568]. AEsopi fabulae lectori non minorem fructum, quam florem ferentes. I Harum interpretes. Guilielmus Goudanus. Adrianus Barlandus. Erasmus Roterodamus. Aulus Gellius. Laurentius Valla. Angelus Politianus. Petrus Crinitus. Ioannes Antonius Campanus. Plinius secundus nouocomensis. Anianus. Guilielmus Hermannus. Nicolaus Gerbellius Phorcensis. Laurentius Abstemius. Rimicius. Accesserunt $\theta$ aliae quaedam fabellae non minus honestae, quàm iucundae; Index fabulas omnes inuenire docebit...London, Guilielmus How. STC (2nd ed.) / 171.5.

- [1570]. The fables of Esope in Englishe with all his lyfe and fortune, howe he was subtyll, wyse, [and] borne in Grece not farre from Troy the greate, in a towne named Amones, he was of al other menne most diffourmed and euill shapen. For he haf a great head, [and] large visage, longe lawes, sharpe eye[s], a short necke, crokebacked, greatebelly. great legges, large feete. And yet that which was worse, he was dombe and could not speak. But notwithstandinge this he had a singuler witte, and was greatly ingenious and subtill in cauillacions, and pleasaunt in woordes, after he came to his speache. vwhereunto is added the Fables of Auyan. And also the Fables of Poge the Florentyne very pleasaunt to reade, London, John Waley. STC (2nd ed.) 181.

Barnes, B. [1593]. Parthenophil and Parthenophe. Sonnettes, Madrigals, Elegies and Odes, London. STC (2nd ed.) 1469.

Bate, J. [1989], "Ovid and the Mature Tragedies: Metamorphosis in Othello and King Lear», Shakespeare Survey, 41, Cambridge: Cambridge University Press, 133-44.

Bate, J. [1993]. Shakespeare and Ovid, Oxford, Clarendon Press.

Covarrubias Orozco, S. DE. [1610]. Emblemas Morales, Madrid, Luis Sánchez, in A. Henkel and A. Schöne (ed.). [1967, 1978]. Emblemata. Handbuch zur Sinnbildkunst des XVI. und XVII. Jahrhunderts, Stuttgart, Metzler, 639.

ElLrodt, R. [2002]. Introduction on La Tragédie du Roi Lear, trans. J.-M. Déprats, G. Venet and L. Cottegnies, in Shakespeare, Tragédies (Euvres complètes II), Paris, Gallimard. 
Fudge, E. [2000]. Perceiving Animals: Human and Beasts in Early Modern English Culture, Urbana and Chicago, University of Illinois Press.

- [2006]. Brutal Reasoning. Animals, Rationality and Humanity in Early Modern England, Ithaca: Cornell University Press.

HaRdison, O.B. [1975]. "Myth and History in King Lear», Shakespeare Quarterly, 26, 227-42.

Herrick. M. T. [1966]. "Hyrcanian Tigers in Renaissance Tragedy», in L. Wallach (ed.), The Classical Tradition: Literary and Historical Studies in Honor of Harry Caplan, Ithaca, Cornell University Press, 559-71.

JowetT, J. [2007]. Shakespeare and Text, Oxford, Oxford University Press.

La Perrière, G. De. [1553]. La Morosophie, Lyons, Macé Bonhomme in A. Henkel and A. Schöne (ed.). [1967, 1978]. Emblemata. Handbuch zur Sinnbildkunst des XVI. und XVII. Jahrhunderts, Stuttgart, Metzler, 1658.

Lycosthenes, C. [1557]. Prodigiorum ac ostentorum chronicon, Basel, H. Petrus.

Релснам H. [1612]. Minerva Britanna Or A Garden Of Heroical Deuises, furnished, and adorned with Emblemes and Impresa's of sundry natures, London, Dight.

Peyré, Y. [1996]. La Voix des mythes dans la tragédie élisabéthaine, Paris, CNRS édition.

Quilligan, M. [2005]. Incest and Agency in Elizabeth's England, Philadelphia, University of Pennsylvania Press.

Reusner, N. [1581]. Emblemata Nicolai Reusneri ic. Partim ethica, et physica: Partim vero Historica, $\theta$ Hieroglyphica, sed ad virtutis, morumque doctrinam omnia ingeniose traducta: $\theta$ in quatuor libros diogesta, cum Symbolis $\theta$ inscriptionibus illustrium $\theta$ clarorum virorum..., Frankfurt, in A. Henkel and A. Schöne (ed.). [1967, 1978]. Emblemata. Handbuch zur Sinnbildkunst des XVI. und XVII. Jahrhunderts, Stuttgart, Metzler, 639.

Rowland, B. [1973]. Animals with Human Faces, a Guide to Animal Symbolism, London, George Allen \& Unwind Ltd.

RuATA, A. S. [2008]. "Approches sémantique et juridique du monstre chez les auteurs latins", in A. Caiozzo, A.-E. Demartini (ed.), Monstre et imaginaire social: approches historiques, Paris, Créaphis, 113-34.

SAndys, G. [1970]. Ovid's Metamorphosis English'd, Mythologized and Represented in Figures, Oxford, John Lichfield, [1632], K. K. Hulley and S. T. Vandersall (ed.), Lincoln, University of Nebraska Press.

Shakespeare, W. [1997]. King Lear, ed. R. A. Foakes, The Arden Shakespeare, $3^{\text {rd }}$ series London, Cengage Learning.

- [2007]. The Tragedy of Othello, The Moor of Venice in Complete Works, J. Bate and E. Rasmussen (ed.), London, Macmillan.

SoelLner. R. [1984]. "King Lear and the Magic of the Wheel», Shakespeare Quarterly, 35:3, 274-289.

StudLey, J. [1566]. The seuenth tragedie of Seneca, entituled Medea, translated out of Latin into English by Iohn Studley. STC (2nd ed.) 22224.

TAcitus, P. C. [1970]. The Annals: books IV-VI, XI-XII, trans. John Jackson, London, W. Heinemann; Cambridge, Harvard University Press.

TAssi, M. [2011]. Women and Revenge in Shakespeare: Gender, Genre, and Ethics. Selinsgrove, Susquehanna University Press.

VIRGIL. [1999]. The Aeneid H. R. Fairclough and G. P. Goold (ed.), The Loeb Classical Library, Cambridge, Massachusetts; London, Harvard University Press.

Wells, St. [2007], King Lear, directed by Trevor Nunn for the Royal Shakespeare Company, The Courtyard Theatre, May-June 2007 in Cahiers Elisabéthains, Special issue 2007, 87-92. 